\title{
Mental Health Exploration And Screening In Adults And Elderly Age Groups
}

\author{
Frans Judea Samosir ${ }^{1 *}$, Victor Trismanjaya Hulu ${ }^{2}$, Hartono, Aida Julpa ${ }^{3}$, \\ Yohana Trisintya Sinurat ${ }^{4}$ \\ 1,2,3,4 Faculty of Medicine, Dentistry and Health Sciences Universitas Prima Indonesia, \\ Medan, North Sumatra, Indonesia. \\ * Corresponding author: \\ Email: fransjudeasamosir@unprimdn.ac.id
}

\begin{abstract}
.
Mental health is an issue that is often discussed during the Covid-19 pandemic. It is critical to understand mental health for realizing its beneficial aspects. Early detection or screening of mental health status is an excellent step to prevent mental health problems. The researchers are interested in screening mental health problems in groups of adults and the elderly. This research design is a descriptive study with a cross-sectional data collection approach. The population in this study were all residents on Jalan Pasar VII Padang Bulan, Medan. The research sample was 139 people who were recruited by non-probability sampling with purposive sampling technique. Data collection was carried out from August to December 2021. The questionnaire used in this study is the Depression Anxiety Stress Scales (DASS 42) questionnaire, which is a tool for measuring stress, anxiety, and depression levels which contains 42 questions. This study shows that from 139 respondents, 54 people (38.85) suffer from mental health problems. Types of mental health problems experienced by respondents were stress as much as 32 people (23\%), 54 people $(38.85 \%)$ experienced anxiety, and 36 people experienced depression (25.9\%). It is crucial for the community to educate themselves on how to manage their mental health in a healthier way.
\end{abstract}

Keywords: stress, anxiety, depression, screening, mental health

\section{INTRODUCTION}

Mental health is an issue that is often discussed during the Covid-19 pandemic. It is critical to understand mental health for realizing its beneficial aspects. World Health Organization (WHO) defines mental health as "a state of well-being in which the individual realizes his or her own abilities, can cope with the normal stresses of life, can work productively and fruitfully, and is able to make a contribution to his or her community" [1], [2]. In addition, [3] also states that our emotional, psychological, and social well-being are all part of our mental health. It impacts the way we think, feel, and act. It also influences how we deal with stress, interact with people, and make decisions. Mental health is vital at all stages of life, including childhood, adolescence, and maturity.Furthermore, mental health has become one of the significant health problems in the world, including in Indonesia. Depression is a prevalent kind of mental illness. It is estimated that 5.0 percent of adults worldwide suffer from depression. Depression is a crucial cause of disability globally and contributes significantly to the 
global illness burden. Women are more likely than males to suffer from depression. Moreover, suicide can be caused by depression [4]. According to Basic Health Research (Riskesdas) records from the Ministry of Health of the Republic of Indonesia, the prevalence of emotional disorders in the population aged 15 years and over, increased from $6 \%$ in 2013 to $9.8 \%$ in 2018. The prevalence of depression sufferers in 2018 was $6.1 \%$ [5].

Furthermore, cardiovascular disease (36.4 percent) is the leading cause of disease and mortality in Indonesia today, followed by neoplasms, maternal-neonatal disorders, respiratory infections, and tuberculosis. However, when it comes to the causes of impairment, mental illnesses (13.4) outnumber these other ailments [6].

Mental-emotional disorders are mental health problems that indicate individuals experience an emotional change which, if it continues can develop into a pathological state [7]. External factors could trigger this emotional change; one of them is the current pandemic. A study has shown that the COVID-19 pandemic impacts people's mental health, mainly due to high levels of stress due to illness caused by viruses, excessive anxiety, and various other influences [8].A mental health survey connected to COVID-19 was undertaken by the Association of Indonesian Mental Medicine Specialists (PDSKJI). Anxiety, sadness, and psychological trauma were the three issues they looked into. As a result, 68 percent of respondents said they were nervous, 67 percent said they were sad, and 77 percent said they had experienced psychological damage.

The study had 1,522 participants, the majority of whom were women (76.1\%), with an average age of 14 years and a maximum age of 71 years. The majority of the respondents were from West Java (23.4\%), DKI Jakarta (16.9\%), Central Java $(15.5 \%)$, and East Java (12.8\%) [9].Screening is a method of determining if someone is at a higher risk of developing a health condition so that early treatment or information may be provided to assist them in making informed decisions [10]. Early detection of mental health status is an excellent step to prevent mental health problems. To find out mental health status can be done with early detection or screening [11]. Besides, a disease that often interferes with mental health, especially someone who has entered old age, is depression. Handling early prevention in minimizing the occurrence of depression in the elderly can be done by taking depression screening measures. Screening has the advantage of being simple, easy, and relatively inexpensive, aiming to detect a disease early in a person so that a complete diagnosis can then be made and early treatment can be given [12].Based on the above description, the researchers are interested in screening mental health problems in groups of adults and the elderly, given the high incidence of mental health disorders related to stress, sadness, and anxiety in Indonesia's population, which continues to expand, as well as the continuous pandemic circumstances. 


\section{METHODS}

This research design is a descriptive study with a cross-sectional data collection approach. The research location is at Jalan Pasar VII Padang Bulan, Medan. The population in this study were all residents on Jalan Pasar VII Padang Bulan, Medan. The research sample was 139 people who were recruited by non-probability sampling with purposive sampling technique. The inclusion criteria in this study were the people living in Pasar VII Padang Bulan, Medan; over 20 years old; and willing to be the sample and fill out the research informed consent.Data collection was carried out from August to December 2021. Respondents filled out the questionnaire given. The questionnaire used in this study is the Depression Anxiety Stress Scales (DASS 42) questionnaire, which is a tool for measuring stress, anxiety, and depression levels which contains 42 questions [13]. The questionnaire that the respondent has filled out is then entered, coded, edited, and then analyzed descriptively using SPSS.

\section{RESULT AND DISCUSSION}

\section{Mental Health Screening among Adults and Elderly}

Univariate analysis was conducted to determine the characteristics of the research data using descriptive statistics. The research variables included the characteristics of respondents, respondents who had mental health problems, respondents who had levels of stress, anxiety, and depression.

Table 1. Characteristics of Respondents

\begin{tabular}{cccc}
\hline Category & Variable & \multicolumn{2}{c}{ Total } \\
\cline { 2 - 4 } Age (years) & & N (139) & Percentage (\%) \\
& $41-50$ & 82 & 59.0 \\
& $51-60$ & 16 & 11.5 \\
& $>60$ & 23 & 16.5 \\
& Male & 18 & 12.9 \\
\hline Sex & Female & 48 & 34.5 \\
Educa & Elementary & 91 & 65.5 \\
\hline & Junior High & 7 & 5.0 \\
& Senior High & 12 & 8.6 \\
& Higher & 81 & 58.3 \\
& Education & 39 & 28.1 \\
\hline Occupation & Unemployed & & \\
& Housewives & 7 & 5.0 \\
& Student & 55 & 39.6 \\
& Driver & 12 & 8.6 \\
& Saloon & 5 & 3.6 \\
& Merchant & 1 & .7 \\
& Entrepreneur & 6 & 4.3 \\
& Farmer & 21 & 15.1 \\
& Staff & 6 & 4.3 \\
& Civil Servant & 16 & 11.5 \\
& & 10 & 7.2 \\
\hline
\end{tabular}


Table 2. Distribution of Mental Health Disorders in Respondents

\begin{tabular}{lcc}
\hline \multicolumn{1}{c}{ Category } & \multicolumn{2}{c}{ Total } \\
\cline { 2 - 3 } & N (139) & Percentage (\%) \\
\hline Normal & 85 & 61.15 \\
Mental Health Disorders & 54 & 38.85 \\
\hline No Anxiety & 85 & 61.2 \\
Anxiety & 54 & 38.8 \\
\hline No Depression & 103 & 74.1 \\
Depression & 36 & 25.9 \\
\hline No Stress & 107 & 77.0 \\
Stress & 32 & 23.0 \\
\hline
\end{tabular}

Table 3. Characteristics of Age, Sex, Education, and Occupation of Respondents with Mental Disorders

\begin{tabular}{|c|c|c|c|c|c|}
\hline \multirow[b]{2}{*}{ Variable } & \multirow[b]{2}{*}{ Category } & \multicolumn{4}{|c|}{ Mental Disorders Total } \\
\hline & & $\begin{array}{c}\text { Yes } \\
(\mathrm{N}=54)\end{array}$ & $\begin{array}{c}\text { Percentage } \\
(\%)\end{array}$ & $\begin{array}{c}\text { No } \\
(\mathrm{N}=85)\end{array}$ & $\begin{array}{c}\text { Percentage } \\
(\%)\end{array}$ \\
\hline \multirow[t]{2}{*}{ Sex } & Male & 17 & 12.23 & 31 & 22.3 \\
\hline & Female & 37 & 26.62 & 54 & 38.85 \\
\hline \multirow[t]{4}{*}{ Age } & $<40$ & 33 & 23.74 & 49 & 35.25 \\
\hline & $41-50$ & 9 & 6.47 & 7 & 5.04 \\
\hline & $51-60$ & 8 & 5.76 & 15 & 10.79 \\
\hline & $>60$ & 4 & 2.88 & 14 & 10.07 \\
\hline \multirow[t]{4}{*}{ Education } & Elementary & 3 & 2.16 & 4 & 2.88 \\
\hline & Junior High & 6 & 4.32 & 6 & 4.32 \\
\hline & Senior High & 4 & 22.3 & 50 & 35.97 \\
\hline & $\begin{array}{c}\text { Higher } \\
\text { Education }\end{array}$ & 14 & 10.07 & 25 & 17.99 \\
\hline \multirow[t]{10}{*}{ Occupation } & Unemployed & 4 & 2.88 & 3 & 2.16 \\
\hline & Housewives & 22 & 15.83 & 33 & 23.74 \\
\hline & Student & 5 & 3.6 & 7 & 5.04 \\
\hline & Driver & 2 & 1.44 & 3 & 2.16 \\
\hline & Saloon & 0 & 0 & 1 & 0.72 \\
\hline & Merchant & 3 & 2.16 & 3 & 2.16 \\
\hline & Entrepreneur & 7 & 5.04 & 14 & 10.07 \\
\hline & Farmer & 3 & 2.16 & 3 & 2.16 \\
\hline & Staff & 6 & 4.32 & 10 & 7.19 \\
\hline & Civil Servant & 2 & 1.44 & 8 & 5.76 \\
\hline
\end{tabular}

\section{Mental Health Exploration among Adults and Elderly}

This study indicates that of the 139 respondents who were reached, the majority consisted of 59\% aged less than 40 years, $65.5 \%$ female, 58.3\% senior high school education, and $39.6 \%$ work as housewives. It is also found that from 139 respondents, there were 85 people in the good mental health category, while 54 people $(38.85 \%)$ experienced mental health problems. Of these mental health problems, 54 people $(38.85 \%)$ experienced anxiety, 36 people experienced depression $(25.9 \%)$ and 32 people $(23 \%)$ experienced stress. Based on sex, the female has a higher number of mental disorders, 37 people (26.62\%). People aged before 40 has the highest number of cases of mental disorders, that is, 33 people $(23.74 \%)$. Those who get higher 
education like universities have a higher number of mental disorders, that is, 14 people $(10.07 \%)$. Lastly, housewives have the highest cases of mental disorders, that is, 22 people $(15.83 \%)$. This is quite worrying because the figures shown are pretty high. This result is in line with previous research in Sorosutan, Yogyakarta, with 192 respondents. The results showed that the majority $(84 \%)$ of the community were mentally healthy, as many as 162 people and the remaining thirty people were at risk of mental disorders. [11]. This finding is sufficient to strengthen the use of the DASS42 Scale as a screening tool or early detection assessment of mental health problems related to stress, depression, and anxiety in the community. A person's mental health is determined by various social, psychological, and biological factors at any one time. Violence and chronic socioeconomic stresses, for example, are well-known threats to mental health.

The most conclusive evidence is linked to sexual assault. Rapid societal change, demanding work environments, gender discrimination, social marginalization, unhealthy lifestyles, physical ill-health, and human rights abuses are linked to poor mental health. People are more sensitive to mental health disorders due to distinct psychological and personality variables. Genetic factors are among the biological dangers [2]. This is in line with the results of this study which show that women are more likely to experience mental disorders. Anxiety, sleeplessness, and burnout were more severe and prevalent in women, particularly young women, than in older age groups. Based on the cut-off scores utilized, the prevalence rates for sleeplessness, burnout, and somatization were notably high. Compared to other age groups, males aged 30-49 years had the highest frequency of mental illness. Symptom severity and caseness were lowest in men and women aged 60-69 years. Men and women in all age groups had equal rates of depression. However, sex-related variations in severity were most significant in the youngest age group and gradually faded with age [14].Someone who is mentally healthy may maximize their talents or potential in dealing with life's obstacles and forming meaningful connections with others. People with poor mental health, on the other hand, will have problems with their mood, cognitive abilities, and emotional control, which can lead to harmful conduct. Mental illness may cause challenges in everyday life, affecting not just interpersonal interactions and relationships but also academic achievement and workplace productivity.

As a result, it is past time for us to adopt a healthy lifestyle [15].National mental health programs should address mental diseases and more prominent factors that promote mental health. Governmental and private policies and programs should include mental health promotion. It is critical to include the education, labor, justice, transportation, environment, housing, and welfare sectors in addition to the health sector [2].This study provides valuable information on the prevalence of mental health problems related to stress, depression, and anxiety in adults and the elderly. However, several factors become limitations in this study, namely: the descriptive approach 
causes this research cannot be generalized and only applies to the community in the research location, the need for varied respondents to judge more objectively from this study, and the existence of bias when respondents conduct self-report through a given questionnaire.

\section{CONCLUSION}

This study shows that from 139 respondents, 54 people (38.85) suffer from mental health problems. Types of mental health problems experienced by respondents were stress as much as 32 people $(23 \%), 54$ people $(38.85 \%)$ experienced anxiety, and 36 people experienced depression $(25.9 \%)$. Mental health problems were found in the group of respondents who were female as many as 37 people $(26.62 \%)$, aged before 40 years were 33 people $(23.74 \%)$, college education level was 14 people $(10.07 \%)$, and with housewives as many as 22 people (15.83\%).People should start educating themselves to be able to understand what risk and protective factors can influence respondents to experience mental health problems related to stress, depression and anxiety. This can be an input for local stakeholders to implement an awareness program for the community of Pasar 7 Padang Bulan. In future research, researchers should be able to examine the factors that influence adults and the elderly to experience mental health problems related to stress, depression, and anxiety.

\section{ACKNOWLEDGMENTS}

The authors are grateful to the Kementerian Pendidikan, Kebudayaan, Riset, dan Teknologi (Ministry of Education and Culture) Republik Indonesia for supporting this project Universitas Prima Indonesia for facilitating this project and to Medan Plus foundation for the partnership to implement Matching Fund 2021. We also thank the community of Pasar 7 Padang Bulan, Medan for the invaluable cooperation.

\section{REFERENCES}

[1] World Health Organization, "Promoting mental health: concepts, emerging evidence, practice (Summary Report)," Geneva, 2004.

[2] World Health Organization, "Mental health: strengthening our response," 2018. [Online]. Available: https://www.who.int/news-room/fact-sheets/detail/mental-healthstrengthening-our-response. [Accessed: 23-Dec-2021].

[3] Mentalhealth.gov, "What Is Mental Health? | MentalHealth.gov," 2018. [Online]. Available: https://www.mentalhealth.gov/basics/what-is-mental-health. [Accessed: 20Dec-2020].

[4] World Health Organization, "https://www.who.int/news-room/fact-sheets/detail/depression,"2021.[Online]. Available: https://www.who.int/news-room/fact-sheets/detail/depression. [Accessed: 23Dec-2021]. 
[5] Kementerian Kesehatan RI, "Hasil Riskesdas 2018," 2018.

[6] Infodatin, "Situasi Kesehatan Jiwa di Indonesia,” Jakarta, 2019.

[7] S. Idaiani and A. Y. Kristanto, "Analisis Gejala Gangguan Mental Emosional Penduduk Indonesia,” Major. Kedokt. Indones., vol. 59, pp. 473-479, 2009.

[8] W. Setyaningrum and H. A. Yanuarita, "Pengaruh Covid-19 Terhadap Kesehatan Mental Masyarakat Di Kota Malang," JISIP (Jurnal Ilmu Sos. dan Pendidikan), vol. 4, no. 4, 2020.

[9] A. Mutia, "https://databoks.katadata.co.id/datapublish/2021/06/17/survei-covid-19menggangu-kesehatan-jiwa-68-orang-depresi,” 2021. .

[10] NHS, "NHS screening," 2021. [Online]. Available: https://www.nhs.uk/conditions/nhsscreening/. [Accessed: 23-Dec-2021].

[11] F. Sambonu, L. Aspuri, N. Farihah, and Y. S. Rosyad, "Deteksi Dini Status Kesehatan Jiwa Warga Sorosutan,” J. Pengabdi. Harapan Ibu, vol. 1, no. 2, p. 41, 2019.

[12] R. N. Pratma and W. A. Puspitosari, "Efektivitas Pelatihan Online Skrining Depresi Pada Lansia Dalam Meningkatkan Pengetahuan Dan Kepercayaan Diri Tenagan Kesehatan," Citra Delima J. Ilm. STIKES Citra Delima Bangka Belitung, vol. 4, no. 2, pp. 39-46, 2020.

[13] I. Ulfah, "Skrining masalah Kesehatan Jiwa dengan Kuesioner DASS-42 pada Civitas UIN Syarif Hidayatullah Jakarta yang memiliki Riwayat Hipertensi,” Jakarta, 2019.

[14] P. Höglund, C. Hakelind, and S. Nordin, "Severity and prevalence of various types of mental ill-health in a general adult population: Age and sex differences," $B M C$ Psychiatry, vol. 20, no. 1, 2020.

[15] Kemenkes RI, "Pengertian Kesehatan Mental," 2018. [Online].Available: https://promkes.kemkes.go.id/pengertian-kesehatan-mental. [Accessed: 23-Dec-2021]. 